disks for frequent repetitions of short announcements, and lacquer-coated metal disks for high-quality gramophone recording, usable (for short life) by direct play-back.

New developments and applications of electronic devices are of vital importance to telecommunications. Facilities for the manufacture of experimental types of thermionic valves enable, for example, knowledge to be built up concerning the causes of their eventual failure and may be helpful towards the provision of the very long-life valves required for submerged repeaters. Such facilities also open the way for development of a few special valves for special uses. Techniques of application, such as are used in electronic computers, are studied ; in fact, an elementary form of electronic computer has been made for dealing with some specific problems of plant provision and arrangement at automatic exchanges.

The main exception to the concentration of effort at the Research Station on telecommunication problems is the work that is being done to explore the practicability of introducing more mechanical processes in the handling of mail. Machines incorporating photo-electric devices can be devised to work at high speed for stacking letters, all with the stamps in correct position to be fed into stamp-cancelling machines, and also for enabling sorters to direct letters into a much larger number of sorting compartments than can be reached by hand. Considerable experimental and development work is necessary before any machines of this kind can be proved to be practicable.

\section{LAND AND POVERTY IN THE MIDDLE EAST}

$\mathrm{D}$

URING the Second World War, the Middle East Supply Centre-the history and achievements of which should be made public before memory fades-acted in various directions as a regional authority over an area embracing about fourteen territories, and extending from Persia to Tripolitania, and from Cyprus to Ethiopia. One of its important short-term objectives was to encourage increased food-production in the Middle East territories, to offset the unavoidable restrictions due to war conditions. This immediate objective threw into sharp relief the need for a comprehensive regional survey of the basic underlying problems of the Middle Eastin particular, land utilization, peasant economy and social organisation-and this task, among others, was given to an Anglo-American Scientific Advisory Mission, the reports of which have now been published by the Stationery Office*. War conditions threw the Middle East territories into close association, and emphasized the fact that they had many common basic obstacles to overcome before any post-war social and economic development was possible.

There were high hopes that some form of regional organisation would succeed the Middle East Supply Centre, to serve these non-political aims. But political inexperience and short-sighted nationalism were too strong. Chatham House has, not for the first time, attempted to fill the gap by publishing a series of studies on social and economic problems in

* The Agricultural Development of the Middle East. By Dr. B. A. Keen. 58. net.

Middle East Sclence. By Dr. E. B. Worthington. 78. 6d. net.

Rural Education and Welfare in the Middle East. By H. B. Allen. Animal Industry in the Middle East. By Dr. N. C. Wright (in

preparation).
(London: H.M. Stationery Office, 1946.) the Middle East. The pamphlet* under review is the first of the series; it deals with Egypt and the Fertile Crescent-Palestine, Transjordan, Syria, Lebanon and Iraq. Dr. Warriner describes the vicious circle enclosing the peasant cultivator in these regions; but the description is equally true for other Middle East countries, and for India. It is essentially an absentee landlord system, with a form of land tenure under which the tenant suffers the maximum disadvantages. Government of the country is largely in the hands of the landlords, most of whom believe their immediate interests would be threatened by any measures designed to improve the tenants' lot. The tenant is wrapped in a fatalism, which is founded on his poverty and helplessness, and reinforced by the technical difficulties of agriculture-especially of peasant farming -in tropical and sub-tropical climates and soils. The social and environmental circumstances that brought about in England the change from the open three-field system to the four-course rotation on enclosed farms do not exist in the Middle East.

Dr. Warriner examines in detail the alternative possibilities. Although most of the suitable land and a good deal of the marginal areas are already settled to capacity or beyond, there are under-populated spaces in the Jezira region of Syria; in Iraq, with better regulation of water supplies, there could be absorbed some five million people, and she points out, as one item in the immensities of the Middle East problem, that this is an authoritative figure for the surplus rural population in Egypt alone.

On the question of quick technical improvements in agricultural methods, Dr. Warriner rightly concludes that these are strictly limited, first, by our present lack of knowledge of tropical agricultural science (a point that cannot be overstressed), and secondly, by the limitations of the existing system of peasant agriculture. Further, such improvements could only be short-range palliatives, for, in the present stage of social emergence of the peasant, any increase in output per acre is more than offset by an increase in the population. At present there appear to be two possibilities only for increasing the output : the development of irrigation under State ownership and control; and, in the drier areas, mechanized dry farming on a village co-operative basis. Both involve a basic change in land tenure customs, and the second especially calls for less, not more, workers per acre.

Dr. Warriner discusses my first proposal for a tripartite organisation that would circumvent the grave obstacles of land ownership and inheritance laws. The proposal is as follows. The Government takes over, on a long lease, land from its present owners, and sub-leases the whole area to a body of the public utility corporation type. This body reconditions the land, divides it into economic units and lets them to tenant farmers for whom it performs certain desirable services--such as bulkmarketing of any cash crops-and from whom it requires certain standards of farming as a condition of the lease. In concluding that this model would not be generally applicable, because it depends on the existence of a special market for which the corporation can finance sales and organise production in relation to the market, Dr. Warriner has rather missed the point of the proposal. It is true that in

* Land and Poverty in the Middle East. By Doreen Warriner. (Middle East Economic and Social Studies.) Pp. vii + 149. (London and New net. 
certain of the examples given by me this aspect is prominent and that it even initiated some of them. But it is not the essential requirement, which is, of course, the circumventing of the land ownership laws: without some such device, an agrarian revolution, expropriation and the rest, are sooner or later inevitable. There is no reason why the proposal should not apply to subsistence crop production; the general financial level would be lower and the operations of the corporation more modest, approximating to what would be done by a cooperative buying and selling society, composed of the tenants themselves. Organisations of this type were working well among the Bulgarian peasant proprietors before the War, and their success was not dependent on the fact that the peasant owned his farm.

At the same time it is clear that lack of capital in the Middle East is an obstacle to rapid development, for it also causes peasant indebtedness to the landlord-moneylender class. Dr. Warriner examines two sources of supply: the war-time sterling credit balances and oil royalties. Both are wasting assets, and both are likely in the present conditions to enrich the few. A speculative possibility briefly mentioned by Dr. Warriner is to form, perhaps under the United Nations, an international agency to promote investment and long-term economic development. This is, in fact, the public utility corporation referred to above, on a somewhat more ambitious scale.

The pamphlet sets a high standard for the succeeding ones. It is lucidly written and the author's personal knowledge of the area has enabled her to set out the essentials of a very complicated situation.

\section{B. A. KEEN}

\section{THE MEDICAL NOBEL INSTITUTES, STOCKHOLM}

$\mathrm{T}$ HE Caroline Institute in Stockholm, in all but name the medical university of the Swedish capital, appointed a committee in 1945 for the planning and building of new laboratories for the three departments of the Medical Nobel Institute. The Department of Biochemistry was founded in 1937 under the direction of Prof. Hugo Theorell ; in 1940, Prof. Ragnar Granit was appointed to a research chair in neurophysiology, established with the aid of a gift from the Wallenberg Foundation in Stockholm, and also supported by the Rockefeller Foundation; this became a Nobel Institute in 1945. At the same time, a third department of the Nobel Institute was created, in cell research, under the direction of Prof. Torbjörn Caspersson.

During the academic year 1947-48, the three departments have been moving into their new and spacious buildings in the 'medical city' which is being created by the Caroline Institute in north-west Stockholm on an old estate known as Norrbacka. The administrative centre, the library and some of the laboratories have already moved out to the new site. The Departments of Physiology and Pharmacology are expected to move out in the autumn.

The Medical Nobel Institute was formally opened in May by the Crown Prince of Sweden and dedicated to the Nobel Foundation by Prof. Bergstrand, president of the Caroline Institute. In addition to Swedish representatives from universities and academies, Scandinavian, British and American guests were present. Great Britain was represented by Prof. E. D. Adrian, foreign secretary of the Royal Society. A dinner presided over by Dr. Ekeberg, president of the Nobel Foundation, concluded the ceremony.

In his speech, Prof. Bergstrand, president of the Caroline Institute, emphasized that the Caroline Institute needed full-time research laboratories engaged in work along the front lines of modern science, for its own sake as well as to enable it to fulfil the important task entrusted to it by the will of Alfred Nobel. The beautiful and well-equipped new laboratories, he went on to say, expressed the confidence of the Caroline Institute in the three directors appointed to lead them. Financially, the three laboratories were a joint effort : the buildings and part of the equipment came from the Nobel Fund, which also supported one of the chairs and part of its running expenses; the Government of Sweden supported the other two chairs and con. tributed to their annual budget; the Wallenberg and Rockefeller Foundations contributed generously to most items of the budget. Prof. Bergstrand concluded his speech by expressing the gratitude of the Caroline Institute to the donors, and, finally, extended a hearty welcome to the guests. Congratulatory addresses were presented by Prof. E. D. Adrian, Prof. W. D. Bronk, foreign secretary of the U.S. National Academy of Sciences, Prof. Linderström. Lang, director of the Carlsberg Institute, Copenhagen, Prof. A. I. Virtanen, director of the Valio Research Laboratory in Biochemistry, Helsinki, and Prof. Mohr, rector of the University of Oslo.

\section{COLOUR TERMINOLOGY}

THE Committee on Colour Terminology appointed in 1941 by the Colour Group of the Physical Society had originally two objectives: $(a)$ to record definitions of terms current in the various groups of people concerned with colour; and $(b)$ to examine the possibility of co-ordinating the terms commonly used. Later, in the light of the Committee's discussions, a third objective was added : $(c)$ to recom. mend a consistent terminology. This was a significant step, as the subject of colour has very wide rami. fications and there was every reason to expect very great difficulty in even approaching consistency. The report now published* shows that, provided a few key changes are made, the terms used by different technical groups can be embodied in a single scheme which avoids gross ambiguities while keeping the specialized terms of particular interests substan. tially intact. The nomenclature of colours them. selves, as distinct from the terms used in describing and specifying them, was expressly excluded from the Committee's consideration.

In drawing up the basic list of current terms with their definitions or mode of use-a list which occupies about two-thirds of the 56 pages of the report-the Committee's net was thrown very wide. The fields covered were colour physics (general, photometric, subjective and colorimetric terms), colour vision, colour-atlas systems (Munsell and Ostwald), technologies involving colour (dyeing, paint and pigment,

* Physical Society. Report on Colour Terminology. By a Committee of the Colour Group. Pp. iv +56 . (London: Physical Society, 1948, 78. net. 